$10(1)(2021) 41-48$
Unnes Science Education Journal
Accredited Sinta 3

\title{
The Gender Equality in CLIS Model and Brain Gym Technique: A Review of Cognitive Learning Outcomes
}

\author{
Yunawati Sele $^{1 \bowtie}$, Fransina Th. Nomleni' ${ }^{2}$, Mega Selviana Sir ${ }^{2}$
}

DOI: http://dx.doi.org/10.15294/usej.v10i1.42794

${ }^{1}$ Biology Education, Faculty of Education, Universitas Timor, Indonesia

${ }^{2}$ Biology Education, Faculty of Teacher Training and Education, Universitas Kristen Artha Wacana, Indonesia

\section{Article Info}

Submitted 24 November 2020 Revised 28 December 2020 Accepted 17 February 2021

\section{Keywords}

Gender Equality, Children Learning In Science Model, Brain Gym technique, Cognitive Learning Outcomes

\begin{abstract}
This study aims at finding out the cognitive learning outcomes of the equality of male and female students in Children Learning in Science (CLIS) that was combined with a Brain Gym. This study is a comparative research. The population of this study were the students of grade XI MIA SMA Negeri 7 Kupang in the academic year of 2018/2019 and the sample of this study were the students of grade XI MIA 1 . The instrument used was a test of cognitive learning outcomes. The data obtained were analyzed using Anakova. The result of ancova test showed that the significance value is 0,675 or greater than alfa value $5 \%$. This means that there are not differences in cognitive learning outcomes between male and female student in CLIS combined with a brain gym. It means that by combining CLIS and Brain Gym technique, the equality of cognitive learning outcomes for male and female students can occur. Providing the same opportunities, the same tasks and the same responsibilities during Children Learning In Science combined with a Brain Gym learning, can minimize the differences in characteristics between genders so that the learning outcomes obtained are equivalent.
\end{abstract}

\section{How to Cite}

Sele, Y., Nomleni, F. T., \& Sir, M. L. (2021). The Gender Equality in CLIS Model and Brain Gym Technique: A Review of Cognitive Learning Outcomes. Unnes Science Education Journal, 10(1), 41-48.

Correspondence Author:

p-ISSN 2252-6617

E-mail: yunawatisele@gmail.com 


\section{INTRODUCTION}

Education is an important process that determines the quality of a nation. Education includes all efforts aimed at growing student awareness of their potential so that the utilization of these potentials can be used as provisions in making adjustments to various situations and challenges that may be encountered in life (Sele et al, 2016; Shilvock, 2018; Dimyati et al, 2018). The quality of the education process must be further improved so that the education can prepare students to enter the industrial revolution 4.0. This is in line with the opinions of Aulbur \& Bigghe (2016), Hartmann \& Bovenschulte (2013) and Pfeiffer (2015) who explain that with good education, students are expected to be able to face various challenges arising from technological developments in the industrial revolution 4.0.

In an effort to maximize the achievement of educational goals, one important topic that needs attention in learning is the problem of student pluralism (Pambudiono et al, 2015). Student pluralism can be interpreted as unique characteristics according to the background of each student (Lerman, 2010; Kantzara, 2013; Colombo, 2013). Among the various diversity of students, a quite visible difference is the difference in gender (Colombo, 2013; Juhannis, 2012). Related to the influence of gender on students' abilities in learning, there have been several studies that have been conducted to uncover these facts. Soraya (2010), Manahal (2011) and Pambudiono et al (2015) revealed that student learning outcomes and other learning outcome variables such as meta-cognitive skills and critical thinking skills can be influenced by gender differences.

The difference in learning outcomes of male and female students can be explained by the facts revealed by previous studies. Elliot, et al (2000), explained that based on memory capacity, language skills and ability to solve mathematical problems, male students have higher visualspatial abilities whereas in verbal abilities, female students have higher abilities. This is in line with reports from Sasser (2010) and Davison (2012) who explained that in verbal abilities, female students are superior compared to male students. Furthermore, Zaidi (2010) proposed that there were differences between the learning process and the language development of male and female students.

The fact that there are differences between male and female students means that in learning including the implementation of the learning model, an equalization effort between students of different gender needs to be done. One of learning model that can be applied is the CLIS learning model. CLIS is a learning model that is based on constructivism theory. The learning based on contructivism theory is a good learning to apply because in such learning, students are encouraged to be actively involved in building their own knowledge and understanding (Oliver, 2000; Driscoll, 2000; Olusegun, 2015, Budiarto, 2015; Fernando\&Marikat, 2017). In CLIS learning, students are required to be actively involved in learning where students are encouraged to actively seek information related to learning material, students are encouraged to build new knowledge, students are encouraged to interpret that knowledge and ultimately students are expected to be able to deduce various facts about new concepts and ideas based on knowledge they have. CLIS learning is done through hands-on/mind-on activities that are expected to develop physical skills and thinking skills of students in reconstructing their ideas. CLIS model consists of several stages: orientation stage, elicitation of ideas stage, restructuring of ideas stage, application of ideas stage and review change in ideas stage (Widiyarti et al, 2012; Pada, 2010; Rustaman, 2010; Hidayati et al, 2015; Budiarto, 2015; Windarwati, 2017).

To increase the effectiveness of CLIS learning, the learning model can be integrated with learning techniques such as Brain Gym technique (Sele, 2019) . Brain Gym is a technique that can be implemented easily but can provide great benefits in improving the quality of learning. In the application of Brain Gym, students are directed to make some simple movements that can stimulate the integration of the work of the right and left brain so that brain functions can be coordinated harmoniously. With harmonious brain coordination, the body's physiological abilities will increase. These abilities include, for instance, memory skills, body coordination abilities, fine and gross motor skills, stress management abilities, and increased individual learning abilities. Several previous studies have reported that Brain Gym is effective to be applied in learning because with easy movements, a cheerful and enjoyable learning atmosphere can be created and at the same time can increase student's learning abilities (Dennison, 2002; Demuth, 2008; Macias et al, 2009; Cahyanto et al, 2016).

Related to the potential of learning models in empowering male and female students' learning outcomes, Ciascai et al. (2011) reported that it was related to students' learning outcome variables. Some studies show that there are differences in learning outcomes between male and 
female students in learning patterns with certain models but there are also those who report that there are no differences in learning outcomes. As an example, Siswati \& Corebima (2017) and Sele (2019) report that in Think Pair Share learning, male and female students have the same metacognitive skills but Pambudiono (2015) reported that in Jigsaw learning, female student learning outcomes are higher. This can indicate that the equality of male and female student learning outcomes in a learning model can be influenced by the characteristics of the learning model used.

Based on these descriptions, the research of the gender equality in Children Learning In Science Model and brain gym technique is important to reveal the facts about the equality of cognitive learning outcomes between male and female students in Children Learning In Science learning combined with a Brain Gym.

\section{METHOD}

This study is a comparative research. The design of the study can be seen in Table 1 .

Table 1. Design of the research

\begin{tabular}{lccc}
\hline Group & $\begin{array}{c}\text { Pre } \\
\text { test }\end{array}$ & $\begin{array}{c}\text { Learning } \\
\text { models }\end{array}$ & Post test \\
\hline Male Student & $\mathrm{O}_{1}$ & $\mathrm{X}$ & $\mathrm{O}_{2}$ \\
\hline Female Student & $\mathrm{O}_{3}$ & $\mathrm{X}$ & $\mathrm{O}_{4}$ \\
\hline Notes: O1 and $\mathrm{O} 3=$ score/value of pre-test, \\
$\mathrm{O} 2$ and $\mathrm{O} 4=$ score/value of post-test, $\mathrm{X}=$ CLIS \\
combined Brain Gym
\end{tabular}

The study was conducted from October to November 2018. The population of this study were the students of class XI MIA SMA Negeri 7 Kupang in the academic year 2018 / 2019, consisting of 5 classes. By using simple random sampling technique, the students of Class XI MIA 1 were determined to be the research sample. Students of class XI MIA 1 consist of 12 male students and 18 female students. Data on cognitive learning outcomes of students before and after treatment were collected with a test of cognitive learning outcomes. The data obtained were then tested for the normality and homogeneity of the data. If after analysis it was known that the data meet the assumption of normal and homogeneity, then the test was carried out with ANCOVA. But If the data did not meet the assumption of normal and homogeneity, then the data analysis would be transferred using the Quade's Rank Analysis of Covariance test as a type of non-para- metric analysis. Data analysis was carried out using IBM statistics 24 software with a significance level of $5 \%$.

\section{RESULT AND DISCUSSION}

Description of the cognitive learning outcomes of male and female students taught by using CLIS combined with a Brain Gym can be seen in Figure 1.

Based on the data showed in Figure 1, it can be seen that there is an increase in the cognitive learning outcomes of male and male students taught by using CLIS combined with a Brain Gym. The average value of pre-test cognitive learning outcomes of male students was 48.33 and the average value of post-test was 75 . This value indicates that an increase of $55.18 \%$. While the average value of pre-test cognitive learning outcomes of female students was 53.06 and the average value of post-test was 77.22 . This value indicates that an increase of $45.53 \%$.

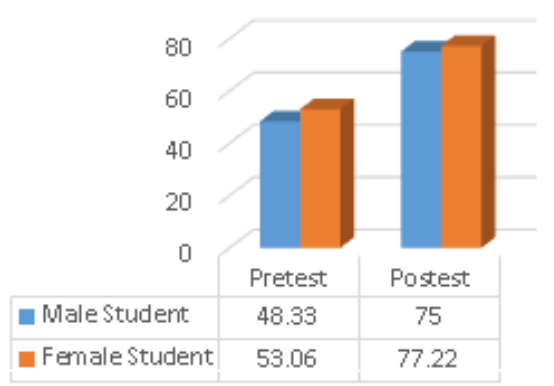

Figure 1. Profile of the average value of pre-test and post-test cognitive learning outcomes

Furthermore, the normality test uses the Kolmogorov-Smirnov One-Sample Test and the homogeneity test uses the Levene's Test of Equality of Error Variances. The results of normality and homogeneity test data can be seen in Table 2. The data in Table 2 shows that the significance value obtained from the One-Sample Kolmogorov-Smirnov Test and Levene's Test is greater than 0.05 for both pre-test and post-test data. Therefore, it can be concluded that the data obtained from this study was normal and homogeneous data so that it can be analyzed using Ancova. Ancova test results of this research data are presented in Table 3.

The calculated $\mathrm{F}$ value of gender that show in Table 3 is 0,180 with a significance value of 0,675 or greater than alfa value $5 \%$. This means that there are not differences in cognitive learning outcomes between male and female student in CLIS combined with a brain gym. 
The result of ancova test show that in CLIS combined with a Brain Gym learning, there is equality in cognitive learning outcomes between male and female students. This shows that the CLIS learning model combined with a Brain Gym can reduce the gaps that might occur due to differences in the cognitive characteristics of students. Wang and Wang (2008) and Chung \& Chang (2016) explain that there are significant differences between the cognitive aspects of male and female students. More detail, Riding and Grimley (1999) revealed that female tend to have a more complete understanding of information than male because female are willing to spend more time to processing the new information and linking that information with the prior knowledge. On the other hand, although male have a lower ability to understand the new information, male are able to process more information than female. Therefore, the equality that occur shows that CLIS learning combined with a Brain Gym can encourage students of different gender to maximize their abilities. This is in accordance with the opinion of Brasilita et al (2018) which explains that with appropriate learning can minimize differences in characteristics between genders so that cognitive learning outcomes achieved will be equal.

Facts about the equality of cognitive learning outcomes can be explained that CLIS learning combined with a Brain Gym can provide equal opportunities for male and female students to engage in learning. This is in line with Sahin (2014) and Hadjar et al (2014) who explained that the essence of gender equality in education is providing equal opportunities to engage in learning. These conditions make students feel be a part of learning and feel facilitated to develop their abilities and qualities.

Providing equal opportunities in CLIS learning can be seen from the process of implementing the learning phase which includes the orientation stage, the elicitation of ideas stage, the restructuring of ideas stage, the application of ideas stage and the review change in ideas stage. In the orientation stage, students are encouraged to focus their attention, realize the importance of the topic of learning and realize the benefits of learning the topic. In the elicitation of ideas stage, students are encouraged to express their initial knowledge and this stage also allows the teacher to explore student's knowledge. These two stages are the stage where each student both male and female students, is given personal responsibility to carry out the learning process. In the third stage, which is the restructuring of ideas stage, each student is given the opportunity to have discussions with other students in a small group. After that students are given the responsibility to report the results of their discussions in class discussions. This stage allows all students, both male and female students to clarify the truth

Table 2. The Result of the Normality and Homogeneity Test of the Cognitive Learning Outcomes

\begin{tabular}{lll}
\hline Data & Statistical Test & Sig \\
\hline Pre-test cognitive learning outcomes & One-Sample Kolmogorov-Smirnov Test & 0.427 \\
& Levene's Test & 0.182 \\
Post-test cognitive learning outcomes & One-Sample Kolmogorov-Smirnov Test & 0.074 \\
& Levene's Test & 0.055 \\
\hline
\end{tabular}

Table 3. The Summary of Ancova Test of the Male and Female Students' Cognitive Learning Outcomes

\begin{tabular}{lccccc}
\hline Source & Type III Sum of Squares & Df & Mean Square & F & Sig \\
\hline Corrected Model & $76.442^{\mathrm{a}}$ & 2 & 38.221 & .150 & .861 \\
Intercept & 19231.473 & 1 & 19231.473 & 75.580 & .000 \\
Pre-test cognitive learning out- & 40.886 & 1 & 40.886 & .161 & .692 \\
comes & 45.810 & 1 & 45.810 & .180 & .675 \\
Gender & 6870.225 & 27 & 254.453 & & \\
Error & 181750.000 & 30 & & & \\
Total & 6946.667 & 29 & & & \\
Corrected Total & & & & &
\end{tabular}

R square $=.011$ (Adjusted $\mathrm{R}$ Squared $=.062$ 
of ideas that they have made in the previous stage. Then in the fourth stage, each student reflects on changes in ideas by comparing initial knowledge and final knowledge after learning.

In this research, CLIS models are also integrated with Brain Gym techniques. The Brain Gym was conducted in opening activities, main activities and closing activities. The frequency of Brain Gym implementation that was adjusted to the conditions of students and learning time. Brain Gym in the opening activities aims to create an initial atmosphere of learning that makes students have a positive attitude to follow the learning. Similarly, Schor (1998), Williams \& Stockdale (2004), Brdar et al (2006) and Putri (2018), explained that in opening activities, teachers are required to be able to create active, relaxed and positive learning situations that motivate students to be ready to participate in learning. Students who have good motivation will carry out the learning process with enthusiasm and have an interest to be actively participated in learning (Filak \& Sheldon, 2008; Irvin et al.,2007; Saeed \& Zyngier, 2012; Taurina, 2015).

Brain Gym in the main activities is done to overcome the boredom of students This is reinforced by the Priambodo report (2016) which explains that the application of Brain Gym makes students relaxed in following learning. Furthermore Dennison (2002) and Purwanto et al (2009) also explained that the implementation of Brain Gym has a positive impact on students because Brain Gym movements can stimulate brain function and have a positive impact on students' physical. Brain Gym allows students to be ready to accept lessons, improve concentration, improve memory and focus, improve communication skills and improve students' ability to manage emotions. While the Brain Gym in the closing activity serves to help students release fatigue so that students are able to conclude learning well. This is important because the closing activity is one of the most important stages of learning to note because at that stage students are given the opportunity to assimilate the lesson and interpret the importance of the lesson (Ganske, 2017).

The explanation of the implementation of the CLIS learning stages combined with a Brain Gym shows that each student gets the same opportunities and responsibilities. This is in accordance with Brasilita et al (2018) which explains that the learning model that results in equality is a learning model that does not differentiate tasks between female and male students and that every female and male student has the same opportunity to collect the value of cognitive re- sults. Furthermore, the personal responsibility of each student will make the learning process better. Bandura (1991), Cook-Sather (2010) and Susetyarini et al (2019) explain that by having responsibilities each student will be able to control his thoughts, actions and personal desires so that students are able to regulate and determine their priorities in learning.

The effort to realize gender equality in CLIS learning combined with a Brain Gym through providing equal opportunities and responsibilities to students is also in line with the opinion of Gondek (2011) which explains that equivalent learning occurs when the teacher gives equal treatment to all students. The treatment given is a treatment that encourages each student to understand their own potential. In learning activities, students must also be given the same opportunity in understanding the material, analyzing the questions, interpreting new information obtained and formulating a new idea based on the learning process it does.

If students are not given the same opportunity in learning, it might be possible to create boredom in students who feel they don't get the teacher's attention. Daschmann (2013) and Alshara (2015) explained that boredom is a negative response that causes students to not have the competencies needed in society because during learning students will not be able to develop cognitive potential and other potential possessed. Other consequences that might occur if boredom in learning is not properly paid attention to is the low ability of students to manage information, low student achievement, low efforts to become better, students become lazy to follow learning and even students drop out of school (Belton \& Priyadharshini, 2007; Pekrundkk, 2010; Dube \& Orpinas, 2009; Fallis \& Opotow, 2003).

Information on the equivalent of the cognitive learning outcomes of male and female students obtained from this study is also in accordance with the report Kusuma (2014) and Brasilita (2016). This shows that in the implementation of learning teachers must try to choose the right learning model that is able to minimize the differences in characteristics between genders so that the learning outcomes obtained are equal learning outcomes between male and female students.

\section{CONCLUSION}

Based on the results of data analysis and discussion, it can be concluded that by combining CLIS and Brain Gym technique, the equality of 
cognitive learning outcomes for male and female students can occur. Providing the same opportunities, the same tasks and the same responsibilities during Children Learning In Science combined with a Brain Gym learning, can minimize the differences in characteristics between genders so that the learning outcomes obtained are equivalent.

\section{REFERENCES}

Al-Shara, I. (2015). Learning and teaching between enjoyment and boredom as realized by the students: A survey from the educational field. $E \mathbf{U}$ ropean Scientific Journal, 11(19).

Aulbur, W., CJ, A., \& Bigghe, R. (2016). Skill development for Industry 4.0. India: Roland Berger.

Bandura, A. (1991). Social Cognitive Theory of Moral Thought and Action. In Handbook of Moral Behavior and Development Volume 1: Theory (pp. 45-103). Hillsdale, New Jersey: Lawrence Erlbaum Associates.

Belton, T. \& Priyadharshini, E. (2007). Boredom and schooling: a cross-disciplinary exploration. Cambridge Journal of Education. 37(4), 579-595.

Brasilita, Y., Zubaidah, S., \& Saptasari, M. (2018). Pengaruh Model Pembelajaran Simas Eric pada Jenis Kelamin Berbeda Terhadap Keterampilan Metakognitif dan Hasil Belajar Kognitif Siswa Biologi di SMAN 6 Malang. Retrieved from https://www.researchgate.net/publication/322286253

Brdar, I., Rijavec, M., \& Loncaric, D. (2006). Goal orientations, coping with school failure and school achievement. European Journal of Psychology of Education, 21(1), 53-70.

Budiarto, F. (2015). Keefektifan Model Pembelajaran CLIS (Children Learning In Science) Terhadap Motivasi Dan Hasil Belajar IPA. Journal of Elementary Education. 4(1), 53-60.

Cahyanto, E.B.,Nugraheni, A. \& Musdalifah, C. (2016). Pengaruh Senam Otak Terhadap Hasil Belajar Kognitif Mahasiswa Pada Pokok Bahasan Konsep Gender Mata Kuliah Kesehatan Reproduksi Dan KB . Retrieved from http:// jurnalplacentum.fk.uns.ac.id/index.php/placentum/article/viewFile/57/21

Chung, 1., \& Chang, R (2016). The Effect of Gender on Motivation and Student Achievement in Digital Game-based Learning: A Case Study of a Contented-Based Classroom. EURASIA Journal of Mathematics Science and Technology Education. 13(6), 2309-2327.

Ciascai, Liliana, \& Lavina, H. (2011). Gender differences in metacognitive skills. A study of the 8th grade pupils in Romania, Procedia - Social and Behavioral Sciences, 29, 396-401.

Colombo, M. (2013). Introduction. Pluralism in education and implications for analysis. Italian Journal of Sociology of Education, 5(2).

Cook-Sather, A. (2010). Students as Learners and
Teachers: Taking Responsibility, Transforming Education, and Redefining Accountability. Curriculum Inquiry, 40(4), 555-575

Daschmann, E. C. (2013). Boredom in School from the Perspectives of Students, Teachers, and Parents. Dissertation. Konstanz: University of Konstanz

Davison, R. C. (2012). Critically thinking about the brain and gender differences. Apply Research to Practice (ARP) Resources. Retrieved from http:// www.engr.psu.edu/awe/ARPAbstracts / Brain/ARP_Abstract_Brain\%20and\%20Gender\%20Differences_Abstract.pdf)

Demuth, E (2008). Pedoman Senam Otak Bagi Guru. Jakarta: Yayasan Kinesiology Indonesia

Dennison, P. (2002). Buku Panduan Lengkap Brain Gym. Jakarta: Gramedia

Dimyati, M., Fauzy, A., \& Musyarof. (2018). Higher Education Provider/College Excellence Mapping Base on Scientific Publication. 2nd International Conference on Statistics, Mathematics, Teaching, and Research. Journal of Physics: Conf. Series 1028 (2018) 012183

Driscoll, M. (2000). Psychology of Learning for Instruction. Boston: Allyn\& Bacon

Dube, S. R., \& Orpinas, P. (2009). Understanding excessive school absenteeism as school refusal behavior. Children \& Schools, 31(2), 87-95.

Elliot, S. N., Kratochwill, T. R., Cook, J. L. \& Travers, J. F. (2000). Educational psycology: effective teaching, effective learning, Third Edition. United States of America: McGraw-Hill Companies, Inc

Fallis, R. \& Opotow, S. (2003) Are students failing school or are schools failing students? Class cutting in high school. Journal of Social Issues, 59(1), 103-119

Fernando, S. Y. J. N., \& Marikat, F. M. M. T. (2017). Constructivist Teaching/Learning Theory and Participatory Teaching Methods. Journal of Curriculum and Teaching. 6(1), 110-122.

Filak, V. F., \& Sheldon, K. M. (2008). Teacher support, student motivation, student need satisfaction, and college teacher course evaluations: testing a sequential path model. Educational Psychology, 28(6), 711-724.

Ganske, K. (2017). Lesson Closure: An Important Piece of the Student Learning. The Reading Teacher. 71(1), 95-100.

Gondek, R. (2011). Promoting Gender Equity in the Science Classroom A Practical Guide to Accessing and Implementing Gender-Fair Strategies. Retreived from https://www.researchgate.net/ publication/237503666_Promoting_Gender_ Equity_in_the_Science_Clasroom_A_Practical_Guide_to_Accessing_and_Implementing_ Gender-Fair_Strategies

Hadjar, A., Krolak-Schwerdt, S., Priem, K,. \& Glock, S. (2014). Gender and educational achievement. Educational Research, 56(2), 117-125,

Hartmann, E. A., \& Bovenschulte, M. (2013). Skills needs analysis for "Industry 4.0" based on roadmaps for smart systems. In SKOLKOVO (Ed.), Using Technology Foresights for Identifying 
Future Skills Needs. Global Workshop Proceedings (pp. 24-36). Moscow

Hidayati., Hartono., \& Mujamil, J. (2015). Penerapan Model Pembelajaran Children Learning InScience (CLIS) Untuk Meningkatkan Hasil BelajarSiswa di Kelas XI IPA SMA Negeri 3 Palembang. Jurnal Penelitian Pendidikan Kimia. 2(1).

Irvin, J. L., Meltzer, J., \& Dukes, M. S. (2007). Student motivation, engagement, andachievement. In Taking Action on Adolescent Llteracy: An Implementation Guide for School Leaders. Association for Supervision and Curriculum Development

Juhannis, H. (2012). The Study of Instilling Plurality Values to The Students of Islamic Schools in Makassar. Journal of Indonesian Islam, 6(1), 145165.

Kantzara, V. (2013). Pluralism and Education: A Compatible Relation. Post-Commentary Notes. Italian Journal of Sociology of Education, 5(2).

Kusuma, \& Anindita S. H. M. (2014). Pengaruh Strategi Pembelajaran Reading Questioning and Answering (RQA), Think Pair Share (TPS), RQA Dipadu TPS dan Perbedaan Gender terhadap Keterampilan Bertanya, Kesadaran Metakognitif, Keterampilan Metakognitif, Pembentukan Karakter dan Hasil Belajar Biologi Siswa Kelas VII SMP Negeri Kota Malang. Tesis tidak diterbitkan, Program Studi Pendidikan Biologi, Program Pascasarjana, Universitas Negeri Malang

Lerman, S. (2010). Theories of Mathematics Education: Is Plurality a Problem? Retrieved from https:// www.researchgate.net/publication/226720307

Macias, M., Nowicka, D., Czupryn, A., Sulejczak, D., Skup, M., et al. (2009). Exercise-Induced Motor Improvement After Complete Spinal CordTransection and its Relation to Expression of Brain Derived NeurotrophicFactor and Presynaptic Markers. BMC Neuroscience

Mahanal, S. (2011). Pengaruh Pembelajaran Berbasis Proyek pada Mata pelajaran Biologi dan Gender terhadap Keterampilan Metakognisi dan Kemampuan Berpikir Kritis Siswa SMA di Malang. Laporan Penelitian. Malang: Lemlit UM.

Oliver, K.M. (2000). Methods for developing constructivism learning on the web. Educational Technology, 40(6).

Olusegun, S. (2015). Constructivism Learning Theory: A Paradigm for Teaching and Learning. Journal of Research \& Method in Education, 5(6), 66-70.

Pada, A.U.T. (2010). Penerapan Model Pembelajaran Children Learning In Science Untuk Meningkatkan Pemahaman Siswa Kelas IV SD Muhammadiyah Condongcatur Pada Konsep Bumi Dan Alam Semesta. Retrieved from https://www.researchgate.net/publication $/ 282977518$

Pambudiono, A., Zubaidah, S., \& Mahanal, S. (2013). Perbedaan Kemampuan Berpikir Dan Hasil Belajar Biologi Siswa Kelas X SMA Negeri 7 Malang Berdasarkan Jender Dengan Penerapan Strategi Jigsaw. Retrieved from: https:// www.researchgate.net/publication/325809484
Pekrun, R., Goetz, T., Daniels, L. M., Stupnisky, R. H., \& Perry, R. P. (2010). Boredom in achievement settings: Exploring control-valueantecedents and performance outcomes of a neglected emotion. Journal of Educational Psychology, 102(3), 531-549.

Pfeiffer, S. (2015). Effects of Industry 4.0 on vocational education and training. (I. of T. A. (ITA), Ed.). Vienna: Austrian Academy of Sciences (ÖAW).

Priambodo, M. G. (2016). Efektivitas Senam Otak (Brain Gym) dalam Menurunkan Tingkat Kejenuhan (Burnout) Belajar Pada Siswa Kelas XI SMA Negeri 11 Yogyakarta. Skripsi. Yogyakarta: Fakultas Ilmu Pendidikan Universitas Negeri Yogyakarta

Purwanto, S., Widyaswati, R., \& Nuryati. (2009). Manfaat Senam Otak (Brain Gym) dalam Mengatasi Kecemasan dan Stres pada Anak Sekolah. Jurnal Kesehatan. 2(1), 81-90.

Puteri, L.H. (2018). The Apperception Approach for Stimulating Student Learning Motivation. International Journal of Education, Training and Learning, 2(1), 7-12.

Riding, R., \& Grimley, M. (1999). Cognitive style and learning from multimedia materials in 11 year children. British Journal of Educational Technology, 30(1), 43- 59.

Rustaman, N. (2010). Materi dan Pembelajaran IPA SD. Jakarta: Universitas Terbuka

Saeed, S., \& Zyngier, D. (2012). How Motivation Influences Student Engagement: a Qualitative Case Study. Journal of Education and Learning, 1(2), 252-267.

Sahin, E. (2014). Gender Equity in Education. Open Journal of Social Sciences, 2, 59-63.

Sasser, L. (2010). Brain differences between genders. Gender Differences in Learning, Genesis 5:1-2, Retrieved from: http://www.faccs.org/assets/ Conventions/Convention- 10/Workshops/ Sasser Gender-Differencesin-Learning.pdf),

Schor, L. I. (1998). Apperception as a Primary Process of the Psyche: Implications for Theory and Practice. Dissertation. Auburn University.

Sele, Y. (2019). Optimizing the potential of CLIS with brain gym: review on human circulatory concepts. Biosfer: Jurnal Pendidikan Biologi, 12(2), 238-248.

Sele, Y. (2019). Analisis Potensi Think Pair Share dalam Pemberdayaan Keterampilan Metakognitif Siswa Laki-laki dan Perempuan. Bio-Edu: Jurnal Pendidikan Biologi. 4(1), 13-21

Sele, Y., Corebima, D., \& Indriwati, S.E. (2016). The analysis of the teaching habit effect based on conventional learning in empowering metacognitive skills and critical thinking skills of senior high school students in Malang, Indonesia. International Journal of Academic Research and Development. 1(5), 64-69.

Shilvock, K. (2018). The Purpose of Education: What Should an American 21st Century Education Value? Empowering Research for Educators, 2(1), 2. Siswati, B. H., \& Corebima, A. D. (2017). The Effect 
of Education Level and Gender on Students' Metacognitive Skills in Malang, Indonesia. Advances in Social Sciences Research Journal, 4(4) 163-168

Soraya, R. 2010. Pengaruh Penerapan Strategi Pembelajaran (PBMP+TPS dan Imkuiri) dan Jenis Kelamin terhadap Hasil Belajar dan Keterampilan Metakognitif Siswa Sekolah Dasar. Skripsi tidak diterbitkan: Malang. Universitas Negeri Malang.

Susetyarini, Rr. E., Permana, T.I., Gunarta, G., Setyawan, D., Latifa, R., \& Zaenab, S. (2019). Motivasi dan tanggung jawab siswa dalam pembelajaran berbasis proyek, sebuah penelitian tindakan kelas. Jurnal Inovasi Pendidikan IPA, $5(1), 1-9$

Taurina, Z. (2015). Students' Motivation and Learning Outcomes: Significant Factors inInternal Study Quality Assurance System. International Disciplinary Subject in Education, 5 (4), 2625-2630

Wang, H. Y., \& Wang, Y. S. (2008). Gender differenc- es in the perception and acceptance of online games. British Journal of Educational Technology, 39(5), 787-806.

Widiyarti., Widayanti., \& Winarti. (2012). Penelitian Pendidikan, dan Penerapan MIPA. Makalah disajikan dalam Seminar Nasional. Fakultas MIPA, Universitas Negeri Yogyakarta.Yogyakarta Juni 2012

Williams, R. L., \& Stockdale, S. L. (2004). Classroom motivation strategies for prospective teachers. TeacherEducator, 39(3), 212-230.

Windarwati. (2017). Pengaruh Model Pembelajaran Children Learning InScience (CLIS) Terhadap Hasil Belajar IPA Siswa Kelas IV di MIN 2 Bandar Lampung. Skripsi. Lampung: Fakultas Tarbiyah dan Keguruan. Universitas Islam Negeri Raden Intan

Zaidi, Z.F. (2010). Gender differences in human brain: A Review. The Open Anatomy Journal, 2010, 2, 37-55, 